\title{
Evaluation of water quality of Çoruh River Basin (Turkey) using some biotic indices
}

\section{Çoruh Nehir Havzası (Türkiye) su kalitesi'nin bazı biyotik indeksler kullanılarak belirlenmesi}

\author{
Hazel Baytaşoğlu* • Ahmet Mutlu Gözler² \\ ${ }^{1}$ Recep Tayyip Erdogan University, Faculty of Fisheries, 53100, Rize, Turkey \\ ${ }^{2}$ Recep Tayyip Erdogan University, Faculty of Fisheries, 53100, Rize, Turkey \\ https://orcid.org/0000-0002-9959-1829 \\ (D) https://orcid.org/0000-0002-0991-6395
}

Baytaşoğlu, H. \& Gözler, A.M. (2021). Evaluation of water quality of Çoruh River Basin (Turkey) using some biotic indices. Ege Journal of Fisheries and Aquatic Sciences, 38(4), 399-409. DOI: 10.12714/egejfas.38.4.01

Abstract: In this study, it was aimed to evaluate the water quality of the Çoruh Basin using BMWP (Biological Monitoring Working Party) index, ASPT (Average Score Per Taxon) index, Shannon-Wiener Diversity Index, EPT (Ephemeroptera Plecoptera Trichoptera taxa), EP (Ephemeroptera Plecoptera taxa) index scores and benthic macroinvertebrates. The benthic macroinvertebrates were collected from 54 stations at the Çoruh basin between 2014-2016 years. Standard hand net (D-frame net) and Ekman-Birge grab were used as sampling tools. As a result of the diagnoses, a total of 7246 individuals belonging to Insecta, Crustacea, Mollusca, Oligochaeta and Plathyhelminthes were obtained. It was determined that the most dominant group was Insecta and the rarest group was Plathyhelminthes. It was observed that the BMWP score ranged between 5 and 94 , and the lowest and highest number of families detected in the stations were 1 and 18 , respectively. It was determined that the Shannon Wiener diversity index value was between $0.54-2.20$, therefore the basin streams generally showed moderate pollution. The results of BMWP index show that the basin streams had mostly show 3rd and 4th class water quality and also biodiversity decreases with the deterioration of the riverbed or exposure to pollution.

Keywords: Biotic indexes, Çoruh River, macroinvertebrates, water quality

Öz: Bu çalışmada BMWP (Biyolojik İzleme Çalışma Grubu) indeksi, ASPT (Her Taksonun Ortalama Değeri) indeksi, Shannon-Wiener Çeşitlilik İndeksi, EPT (Ephemeroptera Plecoptera Trichoptera taxa), EP (Ephemeroptera Plecoptera taxa) indeks skorları ve bentik makroomurgasızlar kullanılarak Çoruh Havzası'nın su kalitesinin değerlendirilmesi amaçlanmıştı. Bentik makroomurgasızlar 2014-2016 yılları arasında havza genelinde seçilen 54 istasyondan örneklenmiş̧̧ir. Örnekleme aleti olarak standart el kepçesi (D-şekilli kepçe) ve Ekman sediment kepçesi kullanılımışır. Yapılan teşhisler sonucu Insecta, Crustacea, Mollusca, Oligochaeta and Plathyhelminthes'e ait toplam 7246 birey elde edilmiştir. En baskın grubun Insecta, en nadir rastlanan grubun Plathyhelminthes olduğu tespit edilmiştir. BMWP skorunun 5-94 arasında değişiği, istasyonlarda tespit edilen en düşük ve en yüksek familya sayılarııın sırasıyla 1 ve 18 olduğu görülmüştür. Shannon Wiener çeşitlilik indeks değerinin 0.54-2.20 arasında olduğu, dolayısıyla havza akarsularının genellikle orta derecede kirlenme gösterdiği belirlenmiştir. BMWP indeks sonuçlarına göre havza akarsularının çoğunlukla 3. ve 4. sınıf su özelliği gösterdiği, akarsu yatağının bozulması veya kirliliğe maruz kalması ile biyoçeşitliliğin azaldığı tespit edilmişsir.

Anahtar kelimeler: Biyotik indeks, Çoruh Nehri, makroomurgasızlar, su kalitesi

\section{INTRODUCTION}

Rivers cover $2 \%$ of the surface fresh water on the earth and contributed to the water cycle such as seas, oceans and lakes. Water pollution in river systems increases in parallel with population and industrialization. It is seen that the factors causing pollution are generally domestic wastes from settlements in the basin, substances such as fertilizers and pesticides mixed from agricultural lands and pollutants from enterprises (Gümrükçüoğlu and Baștürk, 2007). Disturbances in water quality, contamination of any pollutant into the water, and habitat degradation cause damage to living groups (Wimbaningrum et al., 2016). Chemical parameters were used for a long time to determine water quality. However, in the following years, researchers evaluated different organisms as biological quality components and proved their usage in determining the water quality of aquatic communities such as phytoplankton, phytobenthos, macrophytes, macroinvertebrates and fish. Among these groups, macroinvertebrates give different responses to organic pollutants and toxic substances, so they are the one of the most important groups in river.

In the Water Framework Directive (WFD, 2000) adopted by the member states of the European Union, the macroinvertebrates can be used as bioindicator organisms due to their response to pollution. The fact that these groups are found almost everywhere, relatively easy sampling and obtaining sufficient number have enabled them to be used for biomonitoring purposes (Kazancl et al., 1997; Kazancl et al., 2010a; Zeybek and Kalyoncu, 2012). The use of bioindicators to determine water quality in surface waters dates back to the 1800 s. After this date, many researchers have used different mathematical methods to evaluate water quality using these 
organisms. Due to different current conditions, geographical distribution, and biodiversity differences, countries have developed and used different indices. In Turkey, the biotic index studies began with a work in Sakarya and Seyhan catchment areas by Government Water Works in 1992 (DSI, 1992). On this field, the studies have importantly accelerated since 1992 (Kazancı and Dügel, 2000; Kazancı et al., 2003; Duran et al., 2003; Balık et al. 2006; Sukatar et al., 2006; Kazancı and Dügel, 2008; Kazancı et al., 2008; Kazancı et al., 2009; Kazancı, 2009; Kazancı et al., 2010b; Türkmen and Kazancı, 2010a; Türkmen and Kazancı, 2010b; Yıldız et al., 2010; Türkmen and Kazancı, 2011; Topkara et al., 2011; Zeybek et al., 2014; Yıldız et al. 2015; Yorulmaz et al., 2015; Başören and Kazancı, 2016; Zeybek, 2017; Özbek et al. 2019; Tüzün Tereshenko, 2019; Koşal Şahin and Zeybek, 2019). One of these indices used in monitoring studies is the BMWP (Biological Monitoring Working Party) index that was established in 1976 to determine the biological quality of water by family identification of aquatic invertebrates collected from rivers in the UK and Scotland.

The aim of this study is to get an overall view of the benthic macro-invertebrate composition along the Çoruh River Drainage and to assess the water quality assessment of Çoruh River by using various metrics (benthic macroinvertebrate based biotic indices, biodiversity indices, EP and EPT).

\section{MATERIAL AND METHODS}

\section{Study area}

The Çoruh River originates from the west of the Mescit Mountains at an altitude of $3000 \mathrm{~m}$, within the boundaries of Erzurum province. It turns eastward along with the tributaries that are involved in the Bayburt plain and continues to flow along a tectonic line. Together with Tortum and Oltu Streams, it passes through the Yusufeli district and continues to flow towards the north. It leaves from Muratlı Town (Artvin Province) in Turkey and enters the borders of Georgia. It flows into the Black Sea by the delta formed by alluviums it carries from Batumi, the capital of Ajara, which is the semiautonomous province of Georgia. A large part of the drainage area $(91 \%)$ is located within the borders of Turkey, and the rest $(9 \%)$ is located within the borders of Georgia (Akpınar et al., 2009; Baytaşoğlu and Gözler, 2018). The total length is $466 \mathrm{~km}$. In this study, a total of 54 stations (Table 1) were selected on the Çoruh River from the source to the drainage in our country. The map of the sampling stations is given in Figure 1. QGIS geographic information system was used in the map.

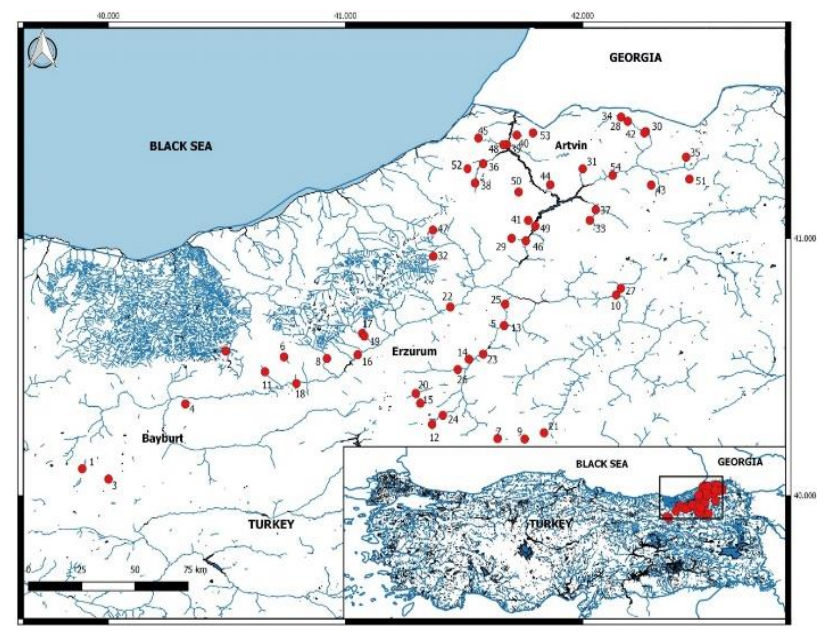

Figure 1. The sampling stations on Çoruh River and its tributaries

Table 1. Some information belonging to stations

\begin{tabular}{|c|c|c|c|c|c|c|}
\hline Station No & Stations Name & Province/Town & Coordinates & $\begin{array}{l}\text { Sampling } \\
\text { Instruments }\end{array}$ & Sampling Date & Substrat \\
\hline 1 & Stream Catıksu & Aydıntepe/Bayburt & $\begin{array}{l}40.476 \mathrm{~N} \\
39.983 \mathrm{E}\end{array}$ & $\begin{array}{l}\text { D-Frame } \\
\text { Net }\end{array}$ & $\begin{array}{l}20.09 .2014 \\
13.5 .2015\end{array}$ & Stony \\
\hline 2 & Stream Yoncalı & Demirözü/Bayburt & \multirow{4}{*}{$\begin{array}{l}40.499 \mathrm{~N} \\
40.566 \mathrm{E} \\
40.132 \mathrm{~N} \\
38.896 \mathrm{E} \\
40.356 \mathrm{~N} \\
40.324 \mathrm{E} \\
40.660 \mathrm{~N} \\
41.668 \mathrm{E}\end{array}$} & \multirow{3}{*}{$\begin{array}{l}\text { D-Frame } \\
\text { Net } \\
\text { D-Frame } \\
\text { Net } \\
\text { D-Frame } \\
\text { Net }\end{array}$} & \multirow{3}{*}{$\begin{array}{l}15.5 .2016 \\
17.8 .2016 \\
21.09 .2014 \\
13.5 .2015 \\
21.09 .2014 \\
13.5 .2015\end{array}$} & Stony, Vegetated \\
\hline 3 & $\begin{array}{l}\text { Güvercindere Irrigation } \\
\text { Channel }\end{array}$ & Demirözü/Bayburt & & & & $\begin{array}{l}\text { Concrete } \\
\text { structure }\end{array}$ \\
\hline 4 & Stream Aydıncık & Merkez/Bayburt & & & & Stony, Vegetated \\
\hline 5 & $\begin{array}{l}\text { Tortum Waterfall } \\
\text { (Lower) }\end{array}$ & Tortum/Erzurum & & $\begin{array}{l}\text { D-Frame } \\
\text { Net }\end{array}$ & $\begin{array}{l}24.09 .2014 \\
14.5 .2015\end{array}$ & Stony, Vegetated \\
\hline 6 & Stream Anur & İspir/Erzurum & \multirow{2}{*}{$\begin{array}{l}40.539 \mathrm{~N} \\
40.740 \mathrm{E} \\
40.221 \mathrm{~N} \\
41.640 \mathrm{E}\end{array}$} & $\begin{array}{l}\text { D-Frame } \\
\text { Net }\end{array}$ & $\begin{array}{l}22.09 .2014 \\
15.5 .2015\end{array}$ & Stony, Vegetated \\
\hline 7 & $\begin{array}{l}\text { Stream Başkale } \\
\text { (Hamidiye) }\end{array}$ & Tortum/Erzurum & & $\begin{array}{l}\text { D-Frame } \\
\text { Net }\end{array}$ & $\begin{array}{l}23.09 .2014 \\
14.5 .2015\end{array}$ & Stony \\
\hline 8 & Stream Capan & İspir Erzurum & \multirow{2}{*}{$\begin{array}{l}40.532 \mathrm{~N} \\
40.921 \\
40.219 \mathrm{~N} \\
41.755 \mathrm{E}\end{array}$} & $\begin{array}{l}\text { D-Frame } \\
\text { Net }\end{array}$ & $\begin{array}{l}15.5 .2016 \\
17.8 .2016\end{array}$ & Stony \\
\hline 9 & $\begin{array}{l}\text { Stream Demirci } \\
\text { (Caylıca) }\end{array}$ & Tortum/Erzurum & & $\begin{array}{l}\text { D-Frame } \\
\text { Net }\end{array}$ & $\begin{array}{l}25.09 .2014 \\
14.5 .2015\end{array}$ & Stony \\
\hline 10 & Stream Alabalık & Olur/Erzurum & $\begin{array}{l}40.779 \mathrm{~N} \\
42.141 \mathrm{E}\end{array}$ & $\begin{array}{l}\text { D-Frame } \\
\text { Net }\end{array}$ & $\begin{array}{l}23.9 .2014 \\
15.5 .2015\end{array}$ & Stony, Vegetated \\
\hline
\end{tabular}


Table 1. Continued

\begin{tabular}{|c|c|c|c|c|c|c|}
\hline 11 & Stream Karataş & İspir/Erzurum & $\begin{array}{l}40.481 \mathrm{~N} \\
40.660 \mathrm{E}\end{array}$ & $\begin{array}{l}\text { D-Frame } \\
\text { Net }\end{array}$ & $\begin{array}{l}15.5 .2016 \\
17.8 .2016\end{array}$ & Stony \\
\hline 12 & Stream Yağcılar & Tortum/Erzurum & $\begin{array}{l}40.277 \mathrm{~N} \\
41.365 \mathrm{E}\end{array}$ & $\begin{array}{l}\text { D-Frame } \\
\text { Net }\end{array}$ & $\begin{array}{l}23.9 .2014 \\
14.5 .2015\end{array}$ & Stony, Vegetated \\
\hline 13 & $\begin{array}{l}\text { Tortum Waterfall } \\
\text { (Upper) }\end{array}$ & Tortum/Erzurum & $\begin{array}{l}40.661 \mathrm{~N} \\
41.668 \mathrm{E}\end{array}$ & $\begin{array}{l}\text { Ekman } \\
\text { Grab, } \\
\text { D-Frame } \\
\text { Net }\end{array}$ & $\begin{array}{l}24.09 .2014 \\
14.5 .2015\end{array}$ & $\begin{array}{l}\text { Stony, Vegetated, } \\
\text { Muddy }\end{array}$ \\
\hline 14 & Stream Dikyar & Tortum/Erzurum & $\begin{array}{l}40.530 \mathrm{~N} \\
41.520 \mathrm{E}\end{array}$ & $\begin{array}{l}\text { D-Frame } \\
\text { Net }\end{array}$ & $\begin{array}{l}16.5 .2016 \\
15.5 .2015\end{array}$ & Stony, Vegetated \\
\hline 15 & Stream Doruklu & Tortum/Erzurum & $\begin{array}{l}40.358 \mathrm{~N} \\
41.314 \mathrm{E}\end{array}$ & $\begin{array}{l}\text { D-Frame } \\
\text { Net }\end{array}$ & $\begin{array}{l}24.09 .2014 \\
15.5 .2015\end{array}$ & Stony, Vegetated \\
\hline 16 & $\begin{array}{l}\text { Stream Yedigöze } \\
\text { (Çoruh River) }\end{array}$ & İspir/ Erzurum & $\begin{array}{l}40.547 \mathrm{~N} \\
41.051 \mathrm{E}\end{array}$ & $\begin{array}{l}\text { D-Frame } \\
\text { Net }\end{array}$ & $\begin{array}{l}25.09 .2014 \\
16.5 .2015\end{array}$ & Stony \\
\hline 17 & $\begin{array}{l}\text { Stream Catakkaya } \\
\text { (upper) }\end{array}$ & Ispir/Erzurum & $\begin{array}{l}40.630 \mathrm{~N} \\
41.070 \mathrm{E}\end{array}$ & $\begin{array}{l}\text { D-Frame } \\
\text { Net }\end{array}$ & $\begin{array}{l}24.09 .2014 \\
16.5 .2015\end{array}$ & Stony \\
\hline 18 & Stream Anur 2 & İspir/Erzurum & $\begin{array}{l}40.435 \mathrm{~N} \\
40.792 \mathrm{E}\end{array}$ & $\begin{array}{l}\text { D-Frame } \\
\text { Net }\end{array}$ & $\begin{array}{l}22.09 .2014 \\
16.5 .2015\end{array}$ & $\begin{array}{l}\text { Stony, } \\
\text { Muddy }\end{array}$ \\
\hline 19 & $\begin{array}{l}\text { Stream Catakkaya } \\
\text { (Lower) }\end{array}$ & Ispir/Erzurum & $\begin{array}{l}40.62 \mathrm{~N} \\
41.079 \mathrm{E}\end{array}$ & $\begin{array}{l}\text { D-Frame } \\
\text { Net }\end{array}$ & $\begin{array}{l}24.09 .2014 \\
16.5 .2015\end{array}$ & Stony \\
\hline 20 & Stream Kaleboynu & Tortum/Erzurum & $\begin{array}{l}40.3970 \mathrm{~N} \\
41.2960 \mathrm{E}\end{array}$ & $\begin{array}{l}\text { D-Frame } \\
\text { Net }\end{array}$ & $\begin{array}{l}23.9 .2014 \\
15.5 .2015\end{array}$ & Stony, Vegetated \\
\hline 21 & $\begin{array}{l}\text { Stream Baskale } \\
\text { (Mercimekli) }\end{array}$ & Tortum/Erzurum & $\begin{array}{l}40.244 \mathrm{~N} \\
41.837 \mathrm{E}\end{array}$ & $\begin{array}{l}\text { D-Frame } \\
\text { Net }\end{array}$ & $\begin{array}{l}23.9 .2014 \\
15.5 .2015\end{array}$ & Stony \\
\hline 22 & $\begin{array}{l}\text { Stream Kılıckaya } \\
\text { Village }\end{array}$ & İspir/Erzurum & $\begin{array}{l}40.7332 \mathrm{~N} \\
41.4417 \mathrm{E}\end{array}$ & $\begin{array}{l}\text { D-Frame } \\
\text { Net }\end{array}$ & $\begin{array}{l}16.5 .2016 \\
17.8 .2016\end{array}$ & Stony \\
\hline 23 & Stream Sapaca & Uzundere/Erzurum & $\begin{array}{l}40.55 \mathrm{~N} \\
41.58 \mathrm{E}\end{array}$ & $\begin{array}{l}\text { D-Frame } \\
\text { Net }\end{array}$ & $\begin{array}{l}17.5 .2016 \\
17.8 .2016\end{array}$ & Stony \\
\hline 24 & Alapınar Fountain & Tortum/Erzurum & $\begin{array}{l}40.312 \mathrm{~N} \\
41.410 \mathrm{E}\end{array}$ & $\begin{array}{l}\text { D-Frame } \\
\text { Net }\end{array}$ & $\begin{array}{l}24.09 .2014 \\
15.5 .2015\end{array}$ & $\begin{array}{l}\text { Concrete } \\
\text { structure }\end{array}$ \\
\hline 25 & Stream Morkaya & Tortum/Erzurum & $\begin{array}{l}40.744 \mathrm{~N} \\
41.673 \mathrm{E}\end{array}$ & $\begin{array}{l}\text { Ekman } \\
\text { Grab, } \\
\text { D-Frame } \\
\text { Net }\end{array}$ & $\begin{array}{l}17.5 .2016 \\
15.5 .2015\end{array}$ & $\begin{array}{l}\text { Stony, Vegetated, } \\
\text { Muddy }\end{array}$ \\
\hline 26 & Stream Uzunkavak & Tortum/Erzurum & $\begin{array}{l}40.490 \mathrm{~N} \\
41.473 \mathrm{E}\end{array}$ & $\begin{array}{l}\text { Ekman } \\
\text { Grab, } \\
\text { D-Frame } \\
\text { Net }\end{array}$ & $\begin{array}{l}17.5 .2016 \\
17.8 .2016\end{array}$ & $\begin{array}{l}\text { Stony, } \\
\text { Muddy }\end{array}$ \\
\hline 27 & Stream Olurdere & Olur/Erzurum & $\begin{array}{l}40.8058 \mathrm{~N} \\
42.1608 \mathrm{E}\end{array}$ & $\begin{array}{l}\text { D-Frame } \\
\text { Net }\end{array}$ & $\begin{array}{l}23.9 .2014 \\
15.5 .2015\end{array}$ & Stony \\
\hline 28 & Stream Mansuret & Şavşat/Artvin & $\begin{array}{l}41.455 \mathrm{~N} \\
42.190 \mathrm{E}\end{array}$ & $\begin{array}{l}\text { D-Frame } \\
\text { Net }\end{array}$ & $\begin{array}{l}27.9 .2014 \\
17.5 .2015\end{array}$ & Stony \\
\hline 29 & Stream Narlık & Yusufeli/Artvin & $\begin{array}{l}41.00 \mathrm{~N} \\
41.70 \mathrm{E}\end{array}$ & $\begin{array}{l}\text { D-Frame } \\
\text { Net }\end{array}$ & $\begin{array}{l}26.9 .2014 \\
19.5 .2015\end{array}$ & Stony \\
\hline 30 & Stream Balıklı & Şavşat/Artvin & $\begin{array}{l}41.4150 \mathrm{~N} \\
42.266 \mathrm{E}\end{array}$ & $\begin{array}{l}\text { D-Frame } \\
\text { Net }\end{array}$ & $\begin{array}{l}27.9 .2014 \\
17.5 .2015\end{array}$ & Stony, Vegetated \\
\hline 31 & Stream Ortaköy & Şavşat/Artvin & $\begin{array}{l}41.27 \mathrm{~N} \\
42.00 \mathrm{E}\end{array}$ & $\begin{array}{l}\text { D-Frame } \\
\text { Net }\end{array}$ & $\begin{array}{l}27.9 .2014 \\
17.5 .2015\end{array}$ & Stony, Vegetated \\
\hline 32 & Stream Altıparmak & Yusufeli/Artvin & $\begin{array}{l}40.93 \mathrm{~N} \\
41.37 \mathrm{E}\end{array}$ & $\begin{array}{l}\text { D-Frame } \\
\text { Net }\end{array}$ & $\begin{array}{l}26.9 .2014 \\
19.5 .2015\end{array}$ & Stony \\
\hline 33 & Stream Torbalı & Ardanuç/Artvin & $\begin{array}{l}41.07 \mathrm{~N} \\
42.03 \mathrm{E}\end{array}$ & $\begin{array}{l}\text { D-Frame } \\
\text { Net }\end{array}$ & $\begin{array}{l}26.9 .2014 \\
17.5 .2015\end{array}$ & Stony \\
\hline 34 & Stream Göknar & Şavşat/Artvin & $\begin{array}{l}41.4712 \mathrm{~N} \\
42.1618 \mathrm{E}\end{array}$ & $\begin{array}{l}\text { D-Frame } \\
\text { Net }\end{array}$ & $\begin{array}{l}27.9 .2014 \\
18.5 .2015\end{array}$ & Vegetated \\
\hline 35 & $\begin{array}{l}\text { Stream Savsat } \\
\text { (Veliköy) }\end{array}$ & Şavşat/Artvin & $\begin{array}{l}41.316 \mathrm{~N} \\
42.436 \mathrm{E}\end{array}$ & $\begin{array}{l}\text { D-Frame } \\
\text { Net }\end{array}$ & $\begin{array}{l}27.9 .2014 \\
18.5 .2015\end{array}$ & Stony, Vegetated \\
\hline 36 & Stream Basköy & Murgul/Artvin & $\begin{array}{l}41.29 \mathrm{~N} \\
41.58 \mathrm{E}\end{array}$ & $\begin{array}{l}\text { D-Frame } \\
\text { Net }\end{array}$ & $\begin{array}{l}29.9 .2014 \\
20.5 .2015\end{array}$ & Stony \\
\hline 37 & Stream Eksinar & Ardanuç/Artvin & $\begin{array}{l}41.1109 \mathrm{~N} \\
42.055 \mathrm{E}\end{array}$ & $\begin{array}{l}\text { D-Frame } \\
\text { Net }\end{array}$ & $\begin{array}{l}28.9 .2014 \\
20.5 .2015\end{array}$ & Stony \\
\hline
\end{tabular}


Table 1. Continued

\begin{tabular}{|c|c|c|c|c|c|c|}
\hline 38 & Stream Damar & Murgul/Artvin & $\begin{array}{l}41.215 \mathrm{~N} \\
41.546 \mathrm{E}\end{array}$ & $\begin{array}{l}\text { D-Frame } \\
\text { Net }\end{array}$ & $\begin{array}{l}29.9 .2014 \\
20.5 .2015\end{array}$ & $\begin{array}{l}\text { Stony } \\
\text { Muddy }\end{array}$ \\
\hline 39 & Stream Deviskel & Borçka/Artvin & \multirow{2}{*}{$\begin{array}{l}41.365 \mathrm{~N} \\
41.680 \mathrm{E} \\
41.401 \mathrm{~N} \\
41.722 \mathrm{E}\end{array}$} & $\begin{array}{l}\text { D-Frame } \\
\text { Net }\end{array}$ & $\begin{array}{l}29.9 .2014 \\
20.5 .2015\end{array}$ & $\begin{array}{l}\text { Stony } \\
\text { Muddy }\end{array}$ \\
\hline 40 & Stream Aralık & Borçka/Artvin & & $\begin{array}{l}\text { D-Frame } \\
\text { Net }\end{array}$ & $\begin{array}{l}29.9 .2014 \\
20.5 .2015\end{array}$ & Stony, Vegetated \\
\hline 41 & Stream Sarıbudak & Artvin & \multirow{3}{*}{$\begin{array}{l}41.070 \mathrm{~N} \\
41.77 \mathrm{E} \\
41.41 \mathrm{~N} \\
42.26 \mathrm{E} \\
41.207 \mathrm{~N} \\
42.289 \mathrm{E}\end{array}$} & $\begin{array}{l}\text { D-Frame } \\
\text { Net }\end{array}$ & $\begin{array}{l}29.9 .2014 \\
20.5 .2015\end{array}$ & Stony \\
\hline 42 & Stream Balıklı 2 & Şavşat/Artvin & & $\begin{array}{l}\text { D-Frame } \\
\text { Net }\end{array}$ & $\begin{array}{l}29.9 .2014 \\
18.5 .2015\end{array}$ & Stony, Vegetated \\
\hline 43 & Stream Arpalı Village & Şavşat/Artvin & & $\begin{array}{l}\text { D-Frame } \\
\text { Net }\end{array}$ & $\begin{array}{l}29.9 .2014 \\
18.5 .2015\end{array}$ & Stony \\
\hline 44 & Stream Seyitler & Artvin & $\begin{array}{l}41.208 \mathrm{~N} \\
41.863 \mathrm{E}\end{array}$ & $\begin{array}{l}\text { D-Frame } \\
\text { Net }\end{array}$ & $\begin{array}{l}28.9 .2014 \\
20.5 .2015\end{array}$ & Stony, Vegetated \\
\hline 45 & Stream Cifteköprü & Borçka/Artvin & $\begin{array}{l}41.39 \mathrm{~N} \\
41.56 \mathrm{E}\end{array}$ & $\begin{array}{l}\text { D-Frame } \\
\text { Net }\end{array}$ & $\begin{array}{l}27.9 .2014 \\
20.5 .2015\end{array}$ & Stony, Vegetated \\
\hline 46 & Stream Kirazalan & Yusufeli/Artvin & $\begin{array}{l}40.99 \mathrm{~N} \\
41.76 \mathrm{E}\end{array}$ & $\begin{array}{l}\text { D-Frame } \\
\text { Net }\end{array}$ & $\begin{array}{l}28.9 .2014 \\
19.5 .2015\end{array}$ & Stony \\
\hline 47 & Cıro Waterfall & Yusufeli/Artvin & $\begin{array}{l}41.032 \mathrm{~N} \\
41.368 \mathrm{E}\end{array}$ & $\begin{array}{l}\text { D-Frame } \\
\text { Net }\end{array}$ & $\begin{array}{l}28.9 .2014 \\
19.5 .2015\end{array}$ & Stony \\
\hline 48 & Stream Cuhala & Cankurtaran/Artvin & $\begin{array}{l}41.3640 \mathrm{~N} \\
41.6655 \mathrm{E}\end{array}$ & $\begin{array}{l}\text { D-Frame } \\
\text { Net }\end{array}$ & $\begin{array}{l}27.9 .2014 \\
20.5 .2015\end{array}$ & Stony \\
\hline 49 & Stream Hızarlı & Artvin & \multirow{2}{*}{$\begin{array}{l}40.86 \mathrm{~N} \\
39.66 \mathrm{E} \\
41.18 \mathrm{~N} \\
41.73 \mathrm{E}\end{array}$} & $\begin{array}{l}\text { D-Frame } \\
\text { Net }\end{array}$ & $\begin{array}{l}27.9 .2014 \\
20.5 .2015\end{array}$ & Stony \\
\hline 50 & Stream Bashatıla & Borçka/Artvin & & $\begin{array}{l}\text { D-Frame } \\
\text { Net }\end{array}$ & $\begin{array}{l}28.9 .2014 \\
20.5 .2015\end{array}$ & Stony, Vegetated \\
\hline 51 & Stream Ballı & Şavşat/Artvin & \multirow{2}{*}{$\begin{array}{l}41.23 \mathrm{~N} \\
42.45 \mathrm{E} \\
41.304 \mathrm{~N} \\
41.631 \mathrm{E}\end{array}$} & $\begin{array}{l}\text { D-Frame } \\
\text { Net }\end{array}$ & $\begin{array}{l}28.9 .2014 \\
18.5 .2015\end{array}$ & Stony \\
\hline 52 & Stream Kokolet 2 & Murgul/Artvin & & $\begin{array}{l}\text { D-Frame } \\
\text { Net }\end{array}$ & $\begin{array}{l}27.9 .2014 \\
18.5 .2015\end{array}$ & Stony \\
\hline 53 & Stream Ogül & Şavşat/Artvin & \multirow{2}{*}{$\begin{array}{l}41.41 \mathrm{~N} \\
41.79 \mathrm{E} \\
41.245 \mathrm{~N} \\
42.126 \mathrm{E}\end{array}$} & $\begin{array}{l}\text { D-Frame } \\
\text { Net }\end{array}$ & $\begin{array}{l}27.9 .2014 \\
18.5 .2015\end{array}$ & $\begin{array}{l}\text { Vegetated, } \\
\text { Muddy }\end{array}$ \\
\hline 54 & Stream Sungu & Şavşat/Artvin & & $\begin{array}{l}\text { D-Frame } \\
\text { Net }\end{array}$ & $\begin{array}{l}27.9 .2014 \\
18.5 .2015\end{array}$ & Stony, Vegetated \\
\hline
\end{tabular}

\section{Indices for determination of biological water quality}

For the determination of water quality by biological methods, BMWP index, ASPT index, EP and EPT taxa values, Shannon-Wiener diversity index were used. The BMWP and ASPT indexes is based on the sensitivity of invertebrates for pollution. The score is between 1 and 10 . It is calculated according to the values of the families in the samples. As the total value approaches 100 , the pollution rate decreases (Kazancl et al., 2010c). ASPT gives the average tolerance values of all taxa in the community. The ASPT value of taxa is found by dividing the BMWP scor by the total number of families at the sampling point. According to the ASPT index, values less than 4 indicate extremely dirty, values between 4-5 indicate moderately polluted, values between 5-6 indicate doubtful waters that are not certain to be of good quality, and values above 6 indicate clean waters (Armitage et al., 1983). The Shannon-Wiener index is also used to interpret water quality. In the Shannon-Wiener index, which is between 0 and 5 , the low score indicates low water quality and the high score indicates high water quality (Shannon ve Wiener 1963, Jorgensen et al., 2005.)

\section{RESULTS AND DISCUSSION}

Sampling studies were carried out at the selected 54 stations where the Turkish side of the Çoruh River basin. Date, station name, station no, province, coordinates, substrate and sampling instrument information belonging to stations are shown in Table 1. As a result of sampling studies and diagnoses in Çoruh River and its tributaries, a total of 7246 individuals were sampled; of them 5283 individuals belonging to Insecta, 1442 individuals to Crustacea, 176 individuals to Mollusca, 208 individuals to Oligochaeta and 137 individuals to Plathyhelminthes. Insecta was the most dominant group among the taxa and Platyhelminthes was the rarest one. In the Insecta group, Ephemeroptera individuals were the most common with $40 \%$ and Odonata individuals were the least encountered with $1 \%$ (Figure 2). 


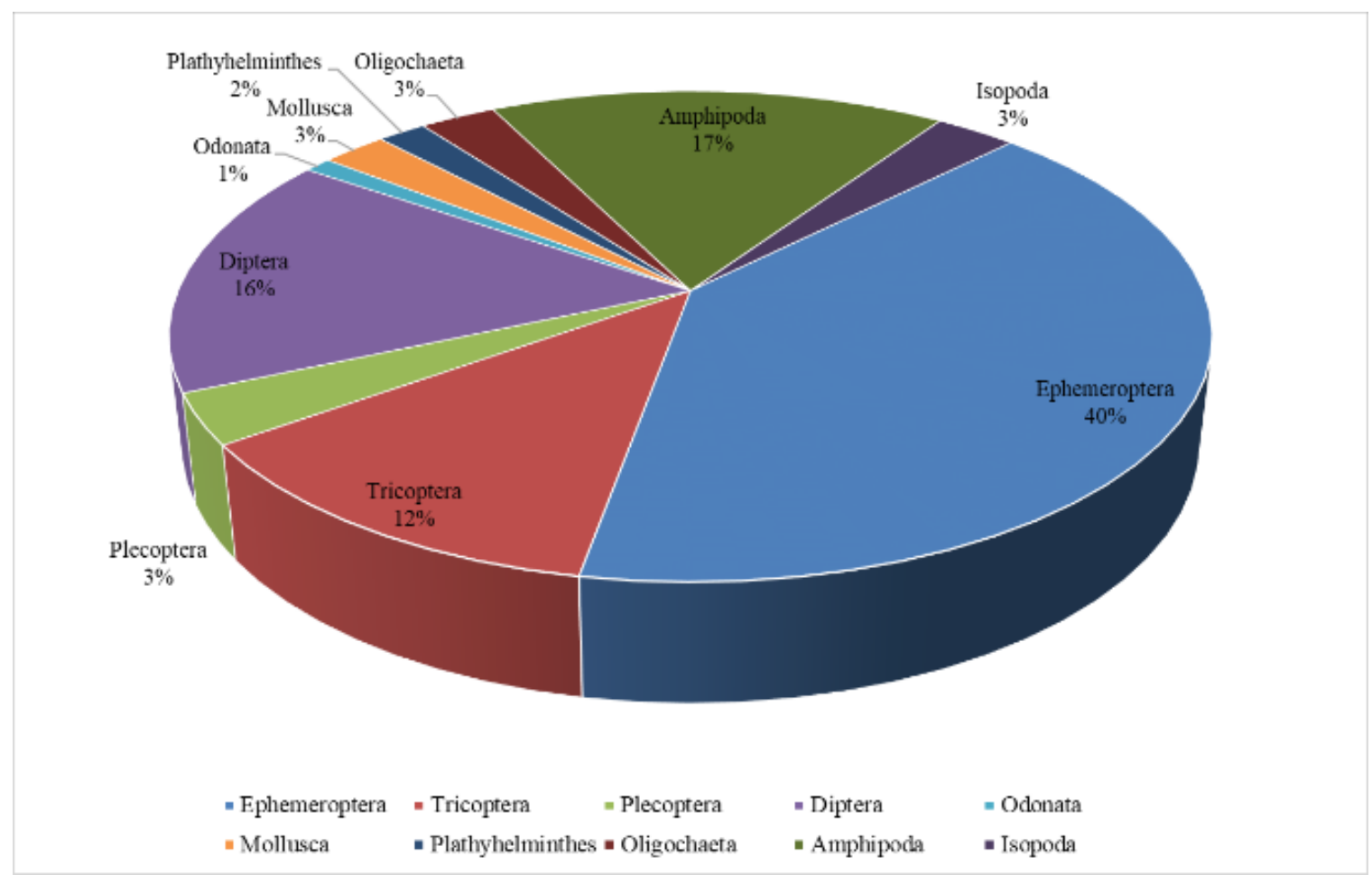

Figure 2. Rational distributions of the determined groups

The taxa observed at the stations were given in Table 2. It has been observed that the stations with high family numbers are far from the settlements and there are no factors that could destroy the streambed in the nearby location.

The highest number of family was found at St -36 (18 families) and the lowest number of family at St -23 (1 families) (Table 3).

It is estimated that the stations with the lowest family numbers are selected from the near point to the main body of the Çoruh River (St-22, St-23), so the diversity is affected by both the flow velocity and the pollution load carried along the stream bed. St-24 station is a concrete structure built for animals to drink water. Although there are living groups transported here by various means, the high level of exposure to daily humanitarian activities caused the diversity to be very low. Although Ephemeroptera, Trichoptera and Plecoptera are good indicators for uncontaminated waters, some families like Baetidae, Caenidae and Hydropsychidae are tolerant to organic pollution and deterioration in the physicochemical properties of streams (Minaya et al., 2013; Kaboré et al., 2016). During the study, Ephemeroptera, Tricoptera and Plecoptera families were sampled both from the upper zones with the least pollution effect and from the locations where wastewater mixtures and structures such as touristic facilities, dams and HEPPs are located. It has been reported that the families Gyrinidae, Dytiscidae, Hydrophilidae and Notonectidae have a high capacity to reflect the ecological and geographical changes that occur throughout the year
(Mauricio da Rocha et al, 2010). In this study, Dytiscidae family was identified from the stations that shows 3rd and 4th class water quality characteristics and Gyrinidae family was also identified at the stations showing 2 nd and 3rd class water quality characteristics.

In the evaluation of the data in this study, the scores of BMWP used to determine water quality with biological data. According to the BMWP score system, the highest scores were 94 (St -36 and St -30) and 85 (St -35), and the lowest BMWP scores were 5 (St -23), 7 (St -22) and 11 (St -24). In studies conducted on different river systems, researchers reported that in locations with better water quality, the diversity of the benthic macroinvertebrates is high, and the diversity decreases as the pollution increases (Duran et. al. 2003, Kalyoncu ve Zeybek, 2011). It has been observed that the stations with low biodiversity in the Çoruh River are selected from the main body with high flow or the fast flowing tributaries, the points where the pollution is concentrated, had a channel modification and the wastes are directly mixed. The stations having 2 nd class water quality characteristics were S9, St-29, St-30 and St-32. St-9 is the closest station to the source of the river and the natural habitat was not disturbed at the St -29 , St -30 and St-32 was selected from the areas officially declared protected areas. Stations with 3rd and 4th class water quality were deformed due to the construction of hydroelectric power plants (St-16, St-18), and mining activities (St -38). In addition, the stations where touristic activities (St- 
44) are intense and streams flowing close to agricultural areas were also $3^{\text {rd }}$ or $4^{\text {th }}$ water quality.

In this study, the ASPT index gave similar results to the BMWP score at many of the stations. However, there were differences between the results to the indices at some of the stations. Although some stations show polluted water characteristics according to the BMWP score, they showed clean water characteristics according to the ASPT index (Table 3).

Shannon-Wiener diversity index is the most widely used diversity index in determining habitat quality using invertebrates. The Shannon index increases as the number and distribution of taxa within a community increases. (Shannon-Wiever, 1949). According to Wilhm and Dorris (1968), if the Shannon-Weaner index value ranges from $>3$ it indicates clean water, 1-3 indicates moderate pollution, $<1$ indicates heavy pollution. In this context, the streams of the Çoruh basin have moderate pollution (between 1-3). Shannon index range from 2.20 to 0.54 in the Çoruh River basin. Shannon index value was calculated at the highest St-10 and the lowest at St-23 (Table 3). It was observed that as the BMWP score decreased, Shannon index values decreased. In these calculations made at the stations, it was determined that the data of the two indexes fit together.

EPT taxa values give an idea about the water quality of the sampling area due to their sensitivity to water pollution. In this study, the highest EPT value was recorded at St-36, St30 and St-32 stations. On the other hand, the lowest EPT value was recorded at St-24 and St-22 stations. St-36 station passes through the settlements and the river bed is partially exposed to trash. Therefore, sampling was made from the upper zone of the river as much as possible. St-32 station was selected from the area known as Altıparmak Mountains Nature Park. Since this area contains endemic species, so it is protected by the local administration. At the St-36 and St-32 stations EP taxa value was calculated as the highest, whereas it was the lowest at St-16, St-22, St-23, St-24 and St-25 stations. Similarly, BMWP, EP and EPT values were used to evaluate the Aksu stream in the Eastern Black sea basin by Kazancl et al. (2010a), and they stated that urbanization, tourism, agricultural activities and the destruction of the river bed changed the community structure of the benthic macroinvertebrates. In this study, we can say that similar reasons may have effective role on the streams of the Çoruh basin.

Ephemerellidae and Caenidae families belonging to Ephemeroptera are pollution tolerant families (Yaman, 2019). In this study, Ephemerellidae family was found in stations with 2nd and 3rd class water characteristics and Caenidae family was found in stations with $3 \mathrm{rd}$ and 4 th class water characteristics, according to BMWP index.

Habitat quality assessment of Altındere Valley was made by using biotic indices and physicochemical parameters by Türkmen and Kazancı, (2016). The families of Heptageniidae, Leptolepiidae, Leuctridae, Nemouridae have been determined as an indicator group for uncontaminated waters. (Türkmen and Kazancl, 2016). In this study, according to BMWP scores, Nemouridae was detected at stations that were slightly polluted, and other families were detected at polluted station.

Studies on determining the water quality by using invertebrate fauna and indices in the Çoruh River Basin, which is a transboundary streams, is very limited. Kazancı et al., (2015) reported 31 taxa from 5 stations on the river. The taxa determined in the present study are different from those reported by Kazancl et al. (2015) because of the numbers and locations of the stations. Kazancl et al., 2015 reported that the main source of pollution of the Çoruh Basin is the interference of urban wastewater into the river system, depending on land usage. In this study, construction of hydroelectric power plants, domestic wastewater and river beds affects the biodiversity in the basin. The two studies are similar in terms of some results obtained.

"Reference condition" is represented unimpaired (or minimally impaired) point in terms of biological, chemical and morphological characters of rivers. In this study, St-36 and St30 had unimpaired properties in terms of BMWP, EP and EPT taxa. Thus these stations can be selected as reference stations.

According to BMWP score and number of EPT-Taxa, Kazancl et al 2015 accepted the first station as a reference habitat in Çoruh River. In this study, St-36 and St-30 had unimpaired properties in terms of BMWP, EP and EPT taxa. Thus, these stations can be selected as reference stations. 
Table 2. The detected families at the stations.

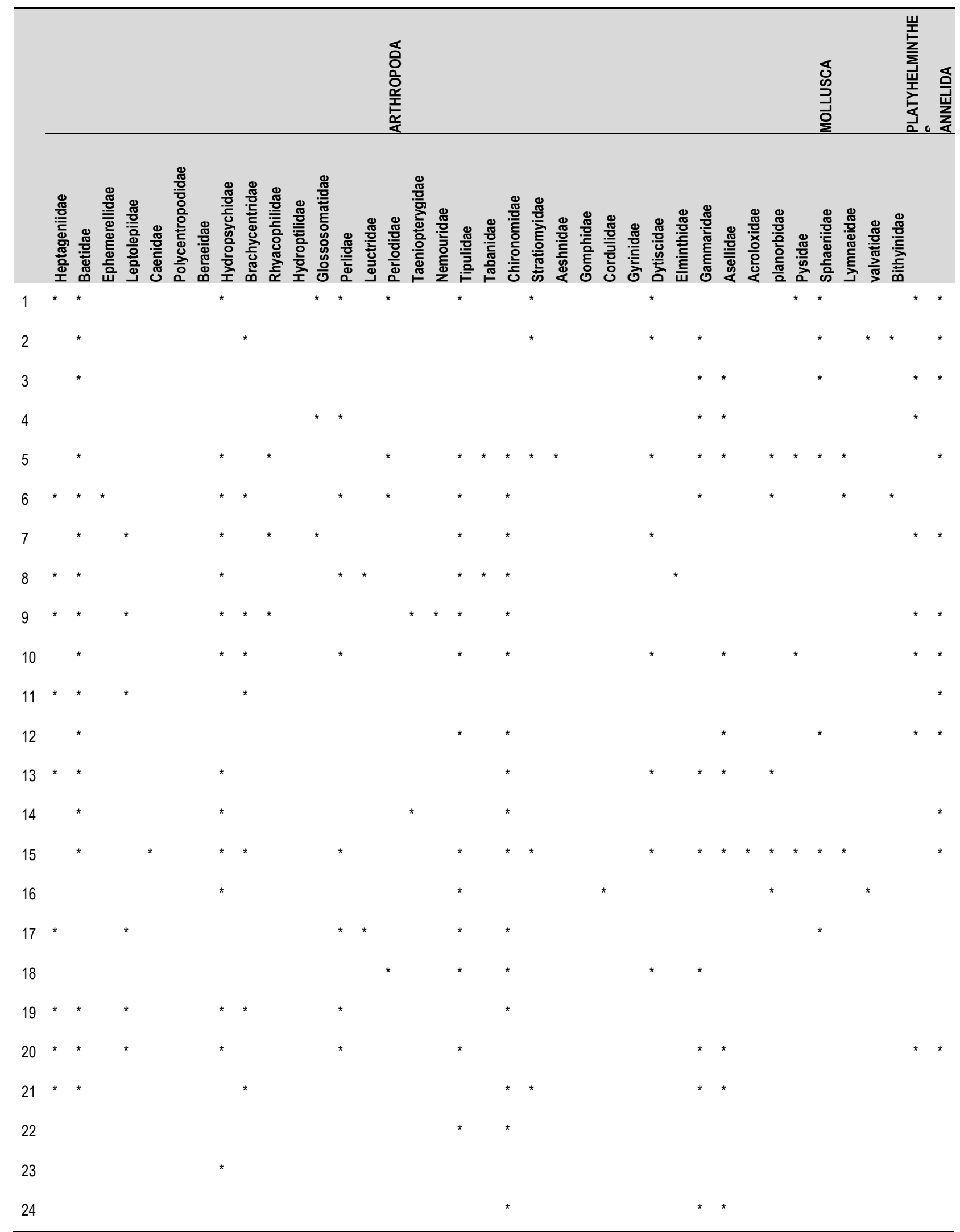




\section{Table 2. Continued}

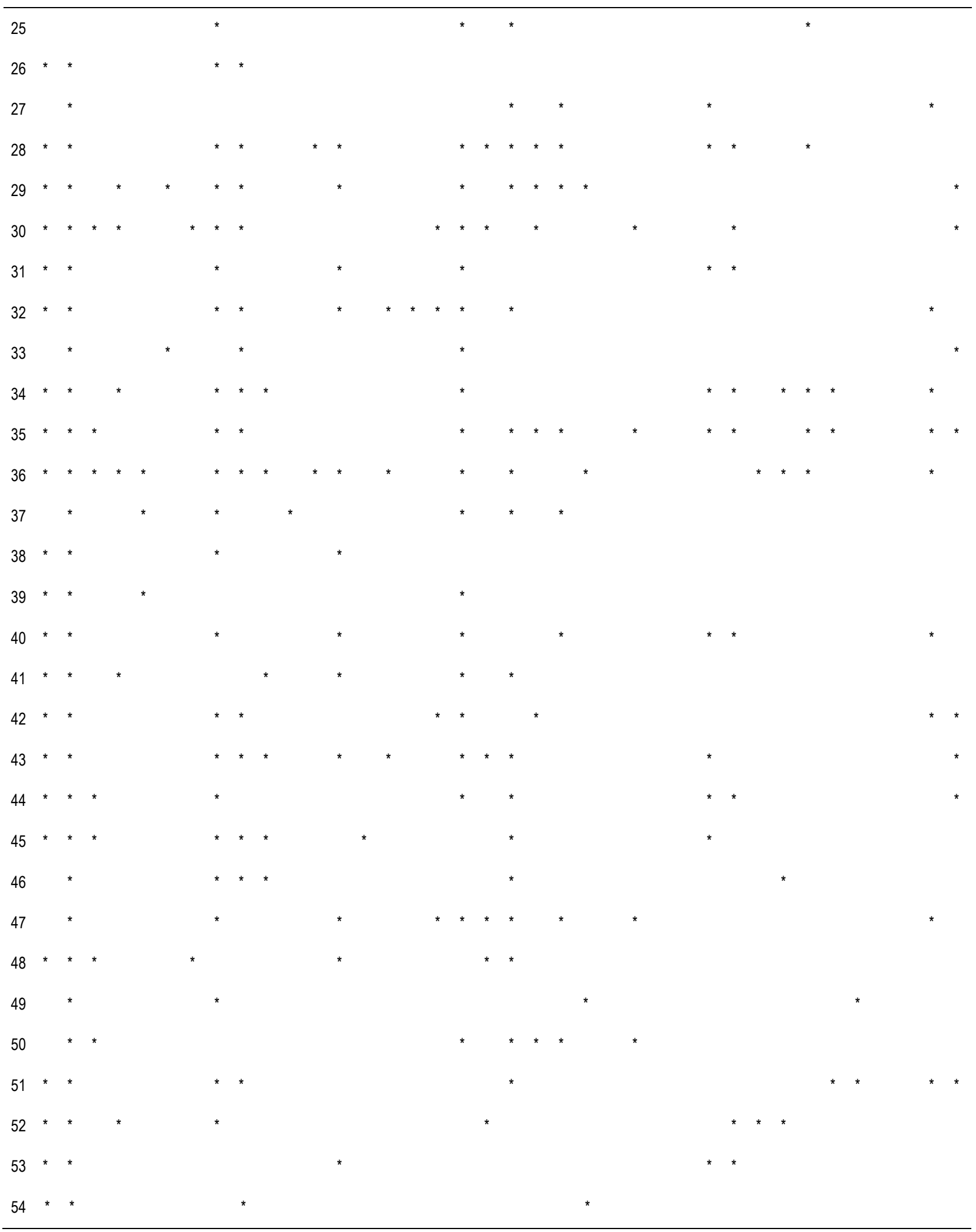


Evaluation of water quality of Çoruh River Basin (Turkey) using some biotic indices

Table 3. Evaluation of stations according to the index values

\begin{tabular}{|c|c|c|c|c|c|c|c|}
\hline Stations & Number of family & BMWP score & class & ASPT & $\begin{array}{c}\text { Shannon-Wiener Index value } \\
\text { (Diversity) }\end{array}$ & EP- Taxa & EPT Taxa \\
\hline 1 & 13 & 61 & 3 & 4.7 & 2.09 & 4 & 6 \\
\hline 2 & 9 & 33 & 4 & 3.7 & 1.4 & 1 & 2 \\
\hline 3 & 6 & 19 & 4 & 3.1 & 1.4 & 1 & 1 \\
\hline 4 & 5 & 32 & 4 & 6.4 & 1.36 & 1 & 2 \\
\hline 5 & 17 & 73 & 2 & 4.2 & 1.76 & 2 & 4 \\
\hline 6 & 13 & 78 & 2 & 6 & 2.13 & 5 & 7 \\
\hline 7 & 10 & 52 & 3 & 5.2 & 1.05 & 2 & 5 \\
\hline 8 & 9 & 55 & 3 & 6.1 & 2.06 & 4 & 4 \\
\hline 9 & 12 & 76 & 2 & 6.3 & 1.54 & 5 & 7 \\
\hline 10 & 11 & 56 & 3 & 5.09 & 2.2 & 2 & 4 \\
\hline 11 & 5 & 35 & 4 & 7 & 1.39 & 3 & 4 \\
\hline 12 & 7 & 26 & 4 & 3.7 & 1.42 & 1 & 1 \\
\hline 13 & 8 & 38 & 4 & 4.75 & 1.96 & 2 & 3 \\
\hline 14 & 5 & 22 & 4 & 4.4 & 1.46 & 2 & 3 \\
\hline 15 & 17 & 65 & 3 & 3.82 & 1.92 & 3 & 5 \\
\hline 16 & 5 & 24 & 4 & 4.8 & 1.37 & 0 & 1 \\
\hline 17 & 7 & 47 & 3 & 6.7 & 1.48 & 4 & 4 \\
\hline 18 & 5 & 31 & 4 & 6.2 & 1.27 & 1 & 1 \\
\hline 19 & 7 & 51 & 3 & 7.2 & 1.33 & 4 & 6 \\
\hline 20 & 10 & 59 & 3 & 5.9 & 1.48 & 4 & 5 \\
\hline 21 & 7 & 39 & 4 & 5.5 & 1.64 & 2 & 3 \\
\hline 22 & 2 & 7 & 5 & 3.5 & 0.6 & 0 & 0 \\
\hline 23 & 1 & 5 & 5 & 5 & 0.54 & 0 & 1 \\
\hline 24 & 3 & 11 & 4 & 3.6 & 1.1 & 0 & 0 \\
\hline 25 & 4 & 12 & 4 & 3 & 0.74 & 10 & 1 \\
\hline 26 & 4 & 29 & 4 & 7.25 & 1 & 2 & 4 \\
\hline 27 & 5 & 25 & 4 & 5 & 1.15 & 1 & 1 \\
\hline 28 & 14 & 72 & 2 & 5.14 & 1.91 & 3 & 6 \\
\hline 29 & 13 & 84 & 2 & 6.46 & 2.18 & 4 & 7 \\
\hline 30 & 14 & 94 & 2 & 6.71 & 1.97 & 5 & 8 \\
\hline 31 & 7 & 51 & 3 & 7.2 & 1.52 & 3 & 5 \\
\hline 32 & 11 & 78 & 2 & 7.09 & 1.68 & 6 & 8 \\
\hline 33 & 5 & 27 & 4 & 5.4 & 1.23 & 1 & 3 \\
\hline 34 & 13 & 68 & 3 & 5.2 & 1.89 & 3 & 6 \\
\hline 35 & 16 & 85 & 2 & 5.3 & 2.03 & 4 & 6 \\
\hline 36 & 18 & 94 & 2 & 5.2 & 1.94 & 6 & 10 \\
\hline 37 & 7 & 37 & 4 & 5.2 & 1.39 & 2 & 4 \\
\hline 38 & 4 & 29 & 4 & 7.25 & 1.09 & 3 & 4 \\
\hline 39 & 4 & 26 & 4 & 6.5 & 0.79 & 3 & 3 \\
\hline 40 & 9 & 56 & 3 & 6.2 & 1.77 & 3 & 4 \\
\hline 41 & 7 & 48 & 3 & 6.8 & 1.29 & 4 & 5 \\
\hline 42 & 9 & 55 & 3 & 6.1 & 1.72 & 3 & 5 \\
\hline 43 & 12 & 64 & 3 & 5.3 & 1.81 & 4 & 7 \\
\hline 44 & 9 & 46 & 3 & 5.1 & 1.84 & 3 & 4 \\
\hline 45 & 9 & 58 & 3 & 6.4 & 1.8 & 4 & 7 \\
\hline 46 & 6 & 31 & 4 & 5.1 & 1.36 & 1 & 4 \\
\hline 47 & 10 & 50 & 3 & 5 & 1.72 & 3 & 3 \\
\hline 48 & 7 & 55 & 3 & 7.8 & 1.5 & 4 & 6 \\
\hline 49 & 4 & 15 & 4 & 3.75 & 0.63 & 1 & 1 \\
\hline 50 & 7 & 39 & 4 & 5.57 & 1.82 & 2 & 3 \\
\hline 51 & 9 & 44 & 3 & 4.9 & 1.33 & 2 & 4 \\
\hline 52 & 8 & 30 & 4 & 3.75 & 0.86 & 3 & 3 \\
\hline 53 & 5 & 36 & 4 & 7.2 & 1.03 & 2 & 3 \\
\hline 54 & 4 & 32 & 4 & 8 & 0.72 & 2 & 3 \\
\hline
\end{tabular}




\section{CONCLUSION}

Çoruh River and its tributaries are located at the intersection of two different features as geological and climatic. Due to its high flow rate, it is the focal point of hydroelectric power plants and dams, as well as for agricultural activities and recreational purposes. The presence of biodiversity hotspot points and bird migration routes increases the importance of the Çoruh Basin. In this study, Çoruh River, which is the fastest flowing stream of Turkey, was evaluated by using macroinvertebrates according to BMWP, Shannon-Wiener, Margalef and Simpson indices. According to BMWP score values, 9 of the stations are II.

\section{REFERENCES}

Akpınar, A., Kömürcü, M.İ., Kankal, M. \& Filiz, M.H. (2009). Çoruh Havzası'ndaki küçük hidroelektrik santrallerin durumu. V. Yenilenebilir Enerji Kaynakları Sempozyumu-2009 (249-254), Diyarbakır, Türkiye.

Armitage P.D., Moss D., Wright, J.F. \& Furse, M.T. (1983). The performance of a new biological water quality score system based on macroinvertebrates over a wide range of unpolluted running water sites. Water Research, 17(3), 333-347. DOI:10.1016/0043-1354(83)90188-4

Arslan, A.B. (2015). Su Çerçeve Direktifine göre biyolojik kalite unsuru: Bentik omurgasız. Uzmanlık Tezi. Orman ve Su İşleri Bakanlığı, Ankara.

Balık, S., Ustaoğlu, M. R., Özbek, M., Yıldız, S., Taşdemir, A. \& IIlhan, A. (2006). Küçük Menderes Nehri'nin (Selçuk- İzmir) aşağı havzasındaki kirliliğin makro bentik omurgasızlar kullanılarak saptanması. Ege Üniversitesi Su Ürünleri Dergisi, 23(1-2), 61-65.

Başören, Ö. \& Kazancı, N. (2016). Water quality assessment of Fırtına Stream (Rize, Turkey) by using various macroinvertebrate based metrics and physicochemical variables, Review of Hydrobiology, 9(1), 1-16.

Baytaşoğlu, H. \& Gözler, A.M. (2018). Seasonal changes of Malacostraca (Crustacea) fauna of the upper Çoruh River Basin (Bayburt Province, Turkey) and its ecological characteristics. Turkish Journal of Fisheries and Aquatic Sciences, 18(3), 367-375. DOI:10.4194/1303-2712-v18_3_02

DSI (1992). Sakarya ve Seyhan havzalarında kirlenme durumlarının incelenmesi ve bu havzalarda kalite sınırlarının tespiti projesi. DSi Genel Müdürlüğü Yayınları Ankara: Türkiye.

Duran, M., Tüzen, M. \& Kayim, M. (2003). Exploration of biological richness and water quality of stream Kelkit, Tokat-Turkey. Fresenius Enviromental Bulletin, 12(4), 368-375.

Gümrükçüoğlu, M. \& Baştürk, O. (2007). Sürdürülebilir su yönetiminde nehir kirliliği üzerine bir çalışma, Türk Mühendis Ve Mimarlar Odası Birliği 2. Su Politikaları Kongresi, (pp. 521-529). Ankara

Jorgensen, S.E., Costanza, R. \& Xu, F.L (2005). Handbook of ecological indicator for assessment of ecosystem health. London, Taylor and Francis Group. DOI:10.1201/9780203490181

Kaboré, I., Moog, O., Alp, M., Guenda, W. \& Koblinger, T. (2016). Using macroinvertebrates for ecosystem health assessment in semi-arid streams of Burkina faso. Hydrobiologia 766,57-74. DOI:10.1007/s10750-015-2443-6

Kalyoncu, H. \& Zeybek, M. (2011). An application of different biotic and diversity indices for assessing water quality: A case study in the Rivers Çukurca and Isparta (Turkey). Af-rican Journal of Agricultural Research, 6 (1), 19-27. DOI:10.5897/AJAR09

Kazancı, N., Girgin, S., Dügel, M. \& Oğuzkurt, D. (1997). Akarsuların çevre kalitesi yönünden değerlendirilmesinde ve izlenmesinde biyotik indeks yöntemi. Ankara: Form Ofset, 100s.

Kazancı, N. \& Dügel, M. (2000). An evaluation of the water quality of Yuvarlakçay Stream, in the Köycegiz-Dalyan protected area SW Turkey. Turkısh Journal of Zoology, 24, 69-80.
Quality, 19 stations III. Quality, 24 stations IV. Quality and 2 stations were determined to be in $\mathrm{V}$. water quality class. According to these findings, it is predicted that the freshwater resources of the Çoruh Basin are under the influence of human activities and if the habitat destruction and pollutants continue or increase, the macroinvertebrate diversity will decrease.

\section{ACKNOWLEDGEMENT}

I would like to thank Salih Kumru and Diana (from Manchester) who helped to prepare the article according to the English spelling rules.

Kazancı, N., Oğuzkurt, D. \& Dügel, M. (2003). Türkiye iç suları araştırma dizisi VII: Beyşehir Gölü'nün limnolojisi, çevre kalitesi, biyolojik çeşitliliği ve korunması. Ankara: İmaj Yayınevi 148s.

Kazancı, N. \& Dügel, M. (2008). Prediction of global climate change impact on structure of aquatic insect assemblages by using species optimum and tolerance values of temperature. Review of Hydrobiology 1(2), 7380.

Kazancı, N., Türkmen, G., Ertunç, Ö., Gültutan, Y., Ekingen, P. \& Öz, B. (2008). Kelkit Çayı'nın su kalitesinin bentik makroomurgasızlar ve fizikokimyasal değişkenler kullanılarak değerlendirilmesi. Review of Hydrobiology, 1(2), 145-160.

Kazancı, N. (2009). Records of Plecoptera (Insecta) species and affects of episodic acidification on physicochemical properties of their habitats in the Eastern Black Sea region and Yeşilırmak River basin. Review of Hydrobiology, 2, 2, 187-197.

Kazancı, N., Öz, B., Dügel, M., Ertunç, Ö \& Türkmen, G. (2009). First faunistic survey and canonical correspondence analysis of interstitial aquatic insect assemblages of running waters in Turkey. Review of Hydrobiology 2(2), 1-11.

Kazancı, N., Ekingen, P., Türkmen, G., Ertunç, Ö., Dügel, M. \& Gültutan, Y. (2010a). Assesment of ecological quality of Aksu stream (Giresun, Turkey) in Eastern Black Sea region by using water framework directive (WFD) methods based on benthic macroinvertebrates. Review of Hydrobiology, 3,(2), 165-184.

Kazancı, N., Türkmen, G., Ertunç, Ö., Ekingen, P., Öz, B. \& Gültutan, Y. (2010b). Su çerçeve direktifi kapsamındaki taban büyük omurgasızlarına dayalı yöntemlerin uygulanması ile Yeşilırmak Nehri'nin ekolojik kalitesinin belirlenmesi. Review of Hydrobiology, 3(2), 89-110

Kazancı N., Öz, B., Dügel, M., Türkmen, G. \& Ertunç, Ö. (2010c). First faunistic and ecological survey of interstitial fauna of streams in Turkey, Verhandlungen des Internationalen Verein Limnologie, 30 (9), 1466. DOI:10.1080/03680770.2009.11902355

Kazancı, N., Türkmen, G., Ekingen, P. \& Başören, Ö. (2013). Preparation of a biotic index (Yeşilırmak-BMWP) for water quality monitoring of Yeşilırmak River (Turkey) by using benthic macroinvertebrates, Review of Hydrobiology, 6 (1),1-29.

Kazancı, N., Türkmen, G. \& Başören, Ö. (2015). Application of BMWP and using macroinvetrebrates to determine the water quality of a transboundary running water, Çoruh River (Turkey). Review of Hydrobiology, 8(2), 119-130.

Koşal Şahin, S. \& Zeybek, M. (2019). Sürgü Çayı (Malatya, Türkiye)'nda makrobentik omurgasızların tür kompozisyonu ve çeşitliliği, Mehmet Akif Ersoy Üniversitesi Fen Bilimleri Enstitüsü Dergisi, 10(1), 60-67. DOI:10.29048/makufebed.529074

Mauricio Da Rocha, J.R., Almeida, J.R., Lins, G.A. \& Durval, A. (2010). Insects as Indicators of Environmental Changing and Pollution: $A$ 
Review of Appropriate Species and Their Monitoring. Holos

Minaya, V., McClain, ME., Moog, O., Omengo, FS., \& Gabriel A., (2013). Scale-dependent effects of rural activities on benthic macroinvertebrates and physico-chemical characteristics in headwater streams of the Mara River, Kenya. Ecological Indicators, 32, 116-122. DOI:10.1016/j.ecolind.2013.03.011

Özbek, M., Tasdemir, A., Cil, E. A., Somek, H., \& Yildiz, S. (2019). Assessing the trophic level of a Mediterranean Stream (Nif Stream, İmir) using benthic macro-Invertebrates and environmental variables. Turkish Journal of Fisheries and Aquatic Sciences, 19(3), 179-190. DOI:10.4194/1303-2712-v19_3_01

Shannon, C.E. \& Weaver, W. (1949). The Mathematical Theory of Communication. Urbana, IL: The University of Illinois Press, 1- 117.

Shannon, C.E. \& Weaver, W. (1963). The Mathematical Theory of Communication. University of Illinois Press, Urbana, $127 \mathrm{p}$.

Sukatar, A., Yorulmaz, B., Ayaz, D. \& Barlas, M. (2006). Emiralem Deresi'nin (İzmir-Menemen) bazı fizikokimyasal ve biyolojik (bentik makroomurgasızlar) özelliklerinin incelenmesi. Süleyman Demirel Üniversitesi Fen Bilimleri Enstitüsü Dergisi, 10 (3), 328-333.

Topkara, E., Özbek, M., Taşdemir, A., Yıldız, S., Balık, S. \& Ustaoğlu, M.R. (2011). Determination of Pollution Level of Yuvarlak Stream (KöyceğizMuğla) by Using Benthic Macroinvertebrates. Journal of Animal and Veterinary Advances $10 \quad$ (9), 1194-1201. DOI:10.3923/javaa.2011.1194.1201

Türkmen, G. \& Kazancı, N. (2010a). Assessment of water quality of Kelkit Stream (Turkey) with application of various macroinvertebrate-based metrics, BALWOIS. Ohrid, Republic of Macedonia.

Türkmen, G. \& Kazancı, N. (2010b). Applications of various biodiversity indices to benthic macroinvertebrate assemblages in streams of a national park in Turkey, Review of Hydrobiology, 3, 111-125.

Türkmen, G. \& Kazancı, N. (2011). Assessment of benthic macroinvertebrate communities of some sites at Kelkit Stream and its tributaries (Yeşilırmak River Basin) with the application of cluster analysis. Review of Hydrobiology, 4(1), 29-45

Türkmen, G. \& Kazancı, N. (2016). Habitat quality assesment of streams in Altındere Valley (Trabzon, Turkey) by using physicochemical variables and various biotic indices based on benthic macroinvertebrates, Review of Hydrobiology, 9 (1), 17.
Environment, 10 (2), 250-262. DOI:10.14295/holos.v10i2.2996

Tüzün Tereshenko, E. (2019). Abant Gölü (Bolu) bentik makroomurgasız faunası ve dağılımı, Ankara Üniversitesi Fen Bilimleri Enstitüsü Biyoloji Anabilim Dalı, Doktora Tezi, Ankara

WFD. (2000). EU Water Framework Directive (WFD) 2000/60/EC. 23.10.2000.

Wilhm, J.L. and Dorris, T.C. (1968). Biological parameters for water quality criteria. BioScience, 18; 477-81. DOI:10.2307/1294272

Wimbaningrum, R., Indriyani, S., Retnaningdyah, C. \& Arisoesilaningsih, E (2016). Monitoring water quality using biotic Indices of benthic macroinvertabrates along surfaces water ecosystems in some tourism areas in East Java, Indonesia. Journal of Indonesian Tourism and Development Studies, 4 (2),81-90. DOI:10.21776/ub.jitode.2016.004.02.06

Yaman, H. (2019). Değirmen Deresi (Kastamonu) Üzerindeki Alabalık İşletmelerinin Bentik Makroomurgasızlara Etkisi, Ankara Üniversitesi Fen Bilimleri Enstitüsü, Yüksek Lisans Tezi, Ankara.

Yıldız, S., Özbek, M., Taşdemir, A. \& Balık, S. (2010). Identification of Predominant Environmental Factors Structuring Benthic Macro Invertebrate Communities: A Case Study in Küçük Menderes Coastal Wetland (Turkey). Fresenius Environmental Bulletin, 19 (1), 30-36.

Yıldız, S., Özbek, M., Taşdemir, A.\& Topkara, E. T. (2015). Assessment of a shallow montane lentic ecosystem (Lake Gölcük, Izmır, Turkey) using benthic community diversity. Ekoloji, 24, 1-13. DOI:10.5053/Ekoloji.2015.34

Yorulmaz, B., Sukatar, A. \& Barlas, M (2015). Comparative analysis of biotic Indices for evaluation of water quality of Esen River in South- West Anatolia, Turkey. Fresenius Environmental Bulletin, 24(1a),188-194

Zeybek, M. \& Kalyoncu, H. (2012). Köprüçay Nehri'nde biyotik indeksler ile çeşitlilik indislerinin karşılaştırmalı olarak incelenmesi, Eğirdir Su Ürünleri Fakültesi Dergisi, 8(1), 42-50.

Zeybek, M., Kalyoncu, H., Karakaş, B. \& Özgül, S (2014). The use of BMWP and ASPT Indices for evaluation of water quality according to macroinvertebrates in Değirmendere Stream (Isparta, Turkey). Turkısh Journal of Zoology, 38(5), 603-613. DOI:10.3906/zoo-1310-9

Zeybek, M. (2017). Macroinvertebrate-based biotic indices for evaluating the water quality of Kargı Stream (Antalya, Turkey). Turkish Journal of Zoology, 41,(3), 476-486. DOI:10.3906/zoo-1602-10 